\title{
A study on the experiences of hygiene requirements among older persons during the COVID-19 epidemic
}

\author{
Tjaša Kamnik, Mojca Jevšnik \\ University of Ljubljana, Faculty of Health Sciences, Ljubljana, Slovenia \\ t.kamnik@gmail.com; mojca.jevsnik@zf.uni-lj.si
}

\begin{abstract}
Introduction: The COVID - 19 epidemic has brought many challenges and changes into our lives. It has significantly changed our lifestyles, which is why many people can see it as a challenge to their mental and physical health. In our research, we were investigating the experiences of hygiene requirements among older persons during the COVID-19 epidemic. Methods: The study was based on a quantitative methodology. A questionnaire was used to carry out a survey. It contained socio - demographic data, data on behaviour in trade during COVID-19 epidemic, data on food handling during COVID-19 epidemic, data on hygiene during COVID-19 epidemic and data about overcoming disease COVID-19. We invited 80 older persons aged 65 or above. Results: Of all the invited older persons, 6 did not respond to the survey. There were 74 respondents, of which we excluded 16 surveys that were not fully completed. There were 58 respondents included in the study, of which $19(32,8 \%)$ men and $39(67,2 \%)$ women. The results showed that behaviour in store during COVID-19 epidemic has changed for $91 \%$ older persons. Respondents observed changes in wearing masks, keeping social distancing, hand disinfection, and infrequent visits to stores. Most respondents ( $78 \%$ ) go to the grocery store less often than before the COVID-19 epidemic, due to risk of infection. In stores, $98 \%$ respondents touch only those foods that they intend to buy, as they are afraid of infection and virus transmission. One-third of respondents do not carry a shopping bag into the kitchen and more than one-third (32 $\%$ ) of all respondents disinfect it, because in this way, they believe that they protect themselves from COVID-19 infection. We have also found that hand hygiene was improved. Due to the fear of infection, $86 \%$ of respondents wash and disinfect their hands more frequently. Almost all respondents ( $97 \%$ ) bought hand sanitiser during the epidemic. Of all respondents, 17 people overcame COVID-19 infection. We were not
\end{abstract}


able to detect a connection between more severe cases of the disease and changed attitudes towards hygiene measures. Discussion and conclusions: The results have shown that older persons are afraid of COVID-19 infection. The fear has an impact on food handling in stores as well as on food preparation at home. Fear of COVID-19 infection is also reflected in improved hand hygiene. People need clear information and directions regarding the handling of food during epidemic, and above all, a way of communication that empowers and reassures people.

Keywords: health, older persons, hygiene requirements, COVID-19 epidemic

\section{Introduction}

SARS-CoV-2 causes an infectious coronavirus disease called 'COVID-19'. The disease occurs in humans in different ways. In $80 \%$ of patients, it has a mild \& course with symptoms such as fever, cough, sore throat, cold, malaise, headache, muscle and joint pain, loss of taste and smell, and digestive problems. In $20 \%$ of patients, the disease is more severe, and $5 \%$ of patients become critically ill and need treatment in the intensive care unit (ICU) (NIJZ, 2020). Infectious disease is transmitted through direct and indirect contact. Directly, it can be transmitted through droplets, that are formed during speaking, coughing, or sneezing. Indirectly, it can be transmitted through touching contaminated surfaces or objects and then touching the eyes, nose, or mouth before cleaning hands (Girum et al., 2020).

The risk of hospitalization or death from COVID-19 infection is greater in the older persons. The older persons are a more vulnerable population as their immune systems weaken over the years, making them more susceptible to infections (NIJZ, 2012). The number of deaths increases with age. In Slovenia, the quantity of people over the age of 65 has doubled since 1981 and amounted to $20.2 \%$ by 2020 (Eurydice, 2021).

The youngest deaths per 100,000 population in Slovenia until 9.3.2021, were recorded in the age group 35-44 years $(n=4)$, followed by the age group $45-54$ years $(n=8)$, and $55-64$ years $(n=32)$. Greater deviation is observed in the age groups $65-74$ years $(n=162), 75-84$ years $(n=695)$ and 85 or older $(n$ = 2826) (Alpaka, 2021). The Center for Disease Control and Prevention (2020) in United States of America estimated that 8 out of 10 reported deaths in 2020 were among persons aged 65 and over. Older persons represent $80 \%$ of all hospitalizations that were caused by COVID-19 (Mueller et al., 2020). The older persons may represent a special group of high-risk patients for the development of COVID-19 with rapidly progressing clinical deterioration. It is more likely that the disease will cause life-threatening respiratory failure and multisystem involvement (Perrotta et al., 2020).

High levels of infection, asymptomatic cases, and uncertainty are the characteristics of infectious diseases, that make these types of disease induce 
more fear among older persons than other diseases. Due to its rapid transmission and unexpected deaths, fear of COVID-19 can become exacerbated (Koçak et al., 2021). Fear of COVID-19 has a major impact on anxiety, depression, and stress; infecting family members or friends can deepen this fear (Koçak et al., 2021).

The COVID-19 epidemic has changed the daily routines of the older persons, their care, and their abilities to remain socially connected. This has triggered new challenges, including anxiety and fear of infection (WHO, 2021), therefore, the purpose of our research was to gain insight into the experience of hygiene requirements during the COVID-19 epidemic among older persons.

\section{Methods}

The main aim of the current research was to discover whether and in what way the behaviour of older persons has changed during the COVID-19 epidemic. We were interested in how the older persons experience the COVID-19 epidemic, and if they are feared of the infectious disease COVID-19. The survey only includes people over the age of 65 . The survey was conducted using a questionnaire, that was to be completed in the respondents' homes. The questionnaire was divided to 4 parts. In the first part, questions focus on the behaviour of older persons in trades during the COVID-19 epidemic. The second part of the questionnaire collects data about food handling during the COVID-19 epidemic, third part includes data on the hygiene of older persons during the COVID-19 epidemic, and the last, fourth part, includes data about overcoming COVID-19 disease and demographic data.

Most questions were of the combined type, followed by closed-ended questions using the yes/no dichotomy (with an added subquestion for clarification), open-ended questions and one question with a measurement scale. Respondents answered the questions after receiving detailed instructions.

\section{Results}

Only persons over 65 years of age were included in the survey. 74 questionnaires were completed, of which 58 were valid. The survey included $66 \%$ women and $34 \%$ men (Table 1 ).

Table 1: Respondents'age

\begin{tabular}{lccccc} 
& \multicolumn{7}{c}{ Respondents' age } \\
Women & $65-70(n)$ & $70-74(n)$ & $75-80(n)$ & 80 or over $(n)$ & Total $(n)$ \\
\hline Men & 12 & 9 & 10 & 7 & 38 \\
\hline Women and men & 5 & 6 & 7 & 2 & 20 \\
\hline
\end{tabular}


The questionnaire gave us an insight into the changed behaviour of older persons as the result of experiencing hygiene requirements during the COVID-19 epidemic. The COVID-19 epidemic changed the behaviour of $91 \%$ of older persons. Respondents observed changes mainly in wearing masks, maintaining social distancing, disinfecting their hands, and visiting stores less frequently. Of the older persons who experienced altered behaviour, $85 \%$ of respondents reported going to the grocery store less often than before the COVID-19 epidemic, due to an increased risk of infection. To avoid more frequent visits to the grocery stores, they buy larger quantities of products, or their relatives make a purchase for of them instead. In stores, $98 \%$ respondents touch only those foods that they intend to buy, as they are afraid of infection and virus transmission. The majority ( $91 \%$ ) of respondents believe that it is easier to keep their distance from other people (in the grocery store) with the wheeled shop\& $\quad$ ping trolley, than the shopping cart.

Table 2 shows the results of the extent to which respondents agree with the claims that COVID-19 infection is transmitted through food or through its packaging, using the Likert rating scale (1 - I do not agree at all, 5 - I totally agree). The results show that majority of respondents are of the opinion that COVID-19 infection spreads with food packaging, but not with the food.

Table 2: Evaluation of COVID-19 disease transmission claims

\begin{tabular}{lccccc} 
& $\begin{array}{c}1-\text { I do not } \\
\text { agree at all } \\
(n)\end{array}$ & $\begin{array}{c}2 \\
(n)\end{array}$ & $\begin{array}{c}3 \\
(n)\end{array}$ & $\begin{array}{c}4 \\
(n)\end{array}$ & $\begin{array}{c}5 \text { - I totally } \\
\text { agree } \\
(n)\end{array}$ \\
$\begin{array}{l}\text { COVID-19 spreads } \\
\text { with food packaging }\end{array}$ & 7 & 3 & 26 & 8 & 14 \\
\hline $\begin{array}{l}\text { COVID-19 spreads } \\
\text { with food }\end{array}$ & 17 & 11 & 19 & 5 & 6 \\
\hline
\end{tabular}

Legend: $n$ - number of respondents

One-third of respondents do not carry a shopping bag into the kitchen and more than one-third ( $32 \%)$ of all respondents disinfect it, because in this way, they believe that they protect themselves from COVID-19 infection.

We were interested in how and in what proportion of older persons' hand hygiene changed (Table 3). We observed a significant interaction between fear of infection and increased hand hygiene. Older persons are aware of the importance of hand hygiene in preventing the disease, but still, more than one-third of respondents $(38 \%)$ are not taught about the correct order of hand washing and disinfection. 


\begin{tabular}{lcc} 
& $\begin{array}{c}Y E S \\
(n)\end{array}$ & $\begin{array}{c}\text { NO } \\
(n)\end{array}$ \\
$\begin{array}{l}\text { Do you wash your hands more often than before } \\
\text { the COVID-19 epidemic? }\end{array}$ & 50 & 8 \\
\hline $\begin{array}{l}\text { Do you disinfect your hands more often than before } \\
\text { the COVID-19 epidemic? }\end{array}$ & 49 & $\mathbf{8}$ \\
\hline $\begin{array}{l}\text { Did you disinfect your hands before the COVID-19 } \\
\text { epidemic? }\end{array}$ & 56 & 2 \\
\hline $\begin{array}{l}\text { Did you buy a hand sanitizer during the COVID-19 } \\
\text { epidemic? }\end{array}$ & 56 & 2 \\
\hline
\end{tabular}

Legend: $n$-number of respondents

Of all respondents, $94 \%$ of older persons wash their hands more often than before the epidemic, as this makes them feel safer. The majority (94\%) have a common fear of infection with the COVID-19. They believe that by washing their hands, they prevent the possibility of the infection spreading. Fear of infection is the main reason that $86 \%$ of older persons disinfect their hands more often than before epidemic. Before the COVID-19 epidemic, $79 \%$ respondents did not disinfect their hands, the rest of respondents disinfect them after seeing a doctor to prevent infections. Almost all respondents (96\%) bought a hand sanitizer to prevent infection with the infectious disease COVID-19.

\section{Discussion}

With our research, we assess the experiences of hygiene requirements among older persons. As we expected, older persons were found to have changed their lifestyles in terms of hygiene measures during the epidemic. They do not socialize, they are lonely, they leave their homes less often, and they feel afraid of being infected with the infectious COVID-19. Measures, such as social distancing, are necessary to reduce the spread of the virus that causes the infectious COVID-19, but at the same time, those measures have a strong impact on the psychological state of older persons, who may feel lonely and feel the fear of getting the disease. Fear of illness, of virus transmission or fear of death as the consequence of COVID-19 disease, can be caused by a variety of psychological states such as depression, anxiety, and stress (Koçak et al., 2021).

Most older persons are afraid of contracting the disease while shopping, so they go to the grocery stores less often and they touch only the products which they intend to buy. The findings of the study showed that COVID-19 epidemic caused fear of contracting the disease among older persons. Most respondents agree that the infectious COVID-19 is transmitted through food packaging. In order for the older persons to buy products safely, National Institute of Public Health NIJZ (2020) recommends cautious behaviour in the grocery store. They recommended wearing masks, keeping social distancing, grocery shopping with 
a shopping list (enabling faster product choice decisions), disinfection of hands on entering and leaving the store, not touching unnecessary products, paying with a pay card, and not touching the face without washing hands.

In China, SARS-CoV-2 was found in early July 2020 on imported food products. It was detected on frozen foods, including their packaging materials. Han and co-researchers (2021) assumed that there is a risk of SARS-CoV-2 transmission between countries and regions. Despite evidence of transmission of the virus through food, there is no evidence that humans become infected by ingesting the virus through food or drink (Food Standards Australia New Zealand, 2021). Food packaging may be contaminated, but that does not pose a particular risk of transmitting the infection. Currently, there is no reliable evidence of virus transmission in contact with contaminated objects (German Federal Institute for Risk Assessment , 2021). So far, there is no more precise data on how long the virus survives or remains on surfaces. Studies show that ¿ it can take hours or weeks, depending on the type of surface, temperature and humidity of the environment (Food Standards Australia New Zealand, 2021). The World Health Organization (2021) states that the virus needs a living host (human or animal) to survive, and that it cannot reproduce on food packaging. They state that food packaging does not need to be disinfected, but recommend washing hands after handling the packaging.

The important interaction between fear of infection and increased hand hygiene is reflected in more frequent hand washing and disinfecting than before the COVID-19 epidemic. Hand hygiene is important in preventing the spread of infectious diseases (Gammon et al., 2020). Various campaigns around the world (e.g. national campaigns COVID-19 - nalezimo se dobrih navad (COVID 19 - Infect yourself with good habits), Higiena rok za vse (Hand hygiene for everyone), and international campaigns Clean your Hands, Seconds save lives clean your hands) in the field of public health have placed the greatest emphasis on hand hygiene practices such as washing and disinfection. Despite informing the public, the target group of respondents is still not entirely sure about the correct order of hand washing and disinfection. After washing hands and before disinfectng them, the drying phase of hands is also important, as in this way we prevent the resistance of microorganisms to alcohol.

There is no such research in Slovenia yet, so it would be sensible to modify it with a larger sample of respondents. The study has some limitations, as the infectious disease COVID-19 has not yet been fully investigated. However, the research is certainly a good basis for further research and a better understanding of the experiences of hygiene requirements among older persons during the COVID-19 epidemic

\section{Conclusion}

The COVID-19 epidemic is a huge challenge for humanity, because it has changed the lifestyles of many older persons. The results of the research show 
that older persons are afraid of infection with infectious disease COVID-19, which affects their changed way of handling food in stores and at home. Fear of infection with COVID-19 is reflected in more often washing and disinfecting hands. On one hand, measures such as social distancing prevent the spread of infectious disease, but on the other hand, can cause psychological distress to older persons. People need clear information and directions regarding the handling of food during epidemic, and above all, a way of communication that empowers and reassures them.

\section{References}

ALPAKA PROJEKT. 2021. Analiza podatkov in vizualizacija širjenja COVID-19 v Sloveniji. Covid19.alpalaka.si. [online]. [viewed: 9. March 2021]. Available from: https://covid19.alpaka.si/.

ASSESSMENT, GERMAN FEDERAL INSTITUTE FOR RISK. 2021. Can the new type of coronavirus be transmitted via food and objects? BfR. [online]. [viewed: 10. March 2021]. Available from: https://www.bfr.bund.de/ $\mathrm{cm} / 349$ /can-the-new-type-of-coronavirus-be-transmitted-via-food-andobjects.pdf.

EURYDICE. 2021. Prebivalstvo: demografsko stanje, jeziki in veroizpovedi. European Commission. [online]. [viewed: 10. March 2021]. Available from: https://eacea.ec.europa.eu/national-policies/eurydice/content/population-demographic-situation-languages-and-religions-77_sl.

FOOD STANDARDS AUSTRALIA NEW ZEALAND. 2021. Transmission of COVID-19 by food and food packaging. [online]. [viewed: 10. March 2021]. Available from: https://www.foodstandards.gov.au/consumer/safety/Pages/Can-COVID-19-be-transmitted-by-food-or-food-packaging.aspx.

GAMMON, J and HUNT, J. 2020. COVID-19 and hand hygiene: the vital importance of hand drying. NIH National Library of Medicine National Center for Biotechnology Information PubMed.gov. [online]. [viewed: 24. June 2021]. Available from: https://pubmed.ncbi.nlm.nih.gov/32972218/.

GIRUM, T., LENTIRO, K., GEREMEW, M., MIGORA, B. and SHEWAMARE, S. 2020. Global strategies and effectiveness for COVID-19 prevention through contact tracing, screening, quarantine, and isolation: a systematic review. BMC Part of Springer Nature, Tropical Medicine and Health. [online]. [viewed: 10. March 2021]. Available from: https://tropmedhealth.biomedcentral.com/articles/10.1186/s41182-020-00285-W.

HAN, J., ZHANG, X., HE,S. and JIA,P. 2020. Can the coronavirus disease be transmitted from food? A review of evidence, risks, policies and knowledge gaps. SpringerLink. [online]. [viewed: 10. March 2021], Available from: https://link.springer.com/article/10.1007/s10311-020-01101-X.

KOÇAK , O., KOÇAK , Ö. E. and YOUNIS, M. 2021. . The Psychological Consequences of COVID-19 Fear and the Moderator Effects of Individuals' 
Underlying Illness and Witnessing Infected Friends and Family. PMC US National Library od Medicine. [online]. [viewed: 24. June 2021]. Available from: https://www.ncbi.nlm.nih.gov/pmc/articles/PMC7917729/.

MUELLER, A.L., MCNAMARA, M.S. and SINCLAIR, D. 2020. Why does COVID-19 disproportionately affect older people? PMC US National Library of Medicine National Institutes of Health. [online]. [viewed: 9. March 2021]. Available from: https://www.ncbi.nlm.nih.gov/pmc/articles/PMC7288963/.

NIJZ. 2020. Koronavirus - pogosta vprašanja in odgovori. Z znanjem do boljšega zdravja. [online]. [viewed: 15.March 2021]. Available from: https:// www.nijz.si/sl/koronavirus-pogosta-vprasanja-in-odgovori\#kako-poteka-bolezen\%2C-kaksni-so-simptomi-in-znaki\%3F.

NIJZ. 2020. Priporočila za starejše v času epidemije nove virusne bolezni COVID-19. Nacionalni inštitut javnega zdravja. [online]. [viewed: 10. March 2021]. Available from: https://www.nijz.si/sites/www.nijz.si/files/uploaded/priporocila_za_starejse_v_casu_epidemije_nove_virusne_bolezni_ covid19.pdf.

NIJZ. 2012. Varnost živil v prehrani nosečnic, otrok in starostnikov. Z znanjem do boljšega zdravja. [online]. [viewed: 15. April 2021]. Available from: https://www.nijz.si/sl/varnost-zivil-v-prehrani-nosecnic-otrok-in-starostnikov.

PERROTTA, F., CORBI G., MAZZEO G., BOCCIA M., ARONNE L., D‘AGNANO V., KOMICI K., MAZZARELLA G., PARRELLA R. and BIANCO A. 2020. COVID-19 and the elderly: insights into pathogenesis and clinical decision-making. SpringerLink. [online]. [viewed: 15. April 2021]. Available from: https://link.springer.com/article/10.1007/s40520-02001631-y.

CENTER FOR DISEASE, CONTROL AND PREVENTION. 2020. Older adults At greater risk of requiring hospitalization or dying if diagnosed with COVID-19. Older Adults. [online]. [viewed: 9. March 2021]. Available from: https://www.cdc.gov/coronavirus/2019-ncov/need-extra-precautions/older-adults.html .

WHO. 2021. Coronavirus (COVID-19) Dashboard. World Health Organization. [online]. [viewed: 10. March 2021]. Available from: https://covid19.who.int/?gclid=CjwKCAiAu8SABh AxEiwAsodSZCmNYHOZtMC_W_6WZuNpvQb-7-6QiuJUA3PCY9oatdTH99LLB2ZnphoCOmIQAvD_Bw. 